Krasnyuk Maxim, Ph.D. of Economics, Associate Professor of the Department of Information Systems in Economics, Kyiv National Economic University named after Vadym Hetman, Kyiv, Ukraine

ORCID ID: 0000-0002-8857-8821

e-mail: krasnyuk@kneu.edu.ua

Hrashchenko Iryna, Ph.D. of Economics, Associate Professor of the Department of Management of Foreign Economic Activity of Enterprises, National Aviation University, Kyiv, Ukraine

ORCID ID: 0000-0002-8735-9061

e-mail: iryljgrafira@nau.edu.ua

Krasniuk Svitlana, Senior Lecturer, Kyiv National University of Technologies and Design, Kyiv, Ukraine

ORCID ID: 0000-0002-5987-8681

e-mail: krasnyuk.so@knutd.edu.ua

Kustarovskiy Oleksandr, graduate student of the Department of Information Systems in Economics, Kyiv National Economic University named after Vadym Hetman, Kyiv, Ukraine

ORCID ID: 0000-0001-6145-1380

e-mail: kust19921987@gmail.com

\title{
Reengineering of a Logistic Company and its Information System Taking into Account Macroeconomic Crisis
}

\begin{abstract}
Introduction. The modern economy is characterized not only by processes of increasing globalization and competition in markets, mobility and internationalization of resources, rapid development of innovative information technologies, but also by rapid spread of crisis phenomena in the middle and between economies - all these factors put forward new requirements for effective corporate governance.

Purpose. Thus, for the sake of stability, not only in the current global market competition, but especially in the context of macroeconomic crisis phenomena, all efficient companies (including logistic) should be able to adapt quickly and efficiently to changes, that is, they must be systemically a daptive.

Results. Taking into account the above-mentioned relevance and results of previous researches of the authors, the methodology of innovative reorganization of the logistic company (LC) was developed through its reengineering within the framework of the implementation of anti-crisis management policy.

It should be noted that an appropriate adequate and effective information system is an integral part of any management system. Therefore, without a relevant, effective and adaptive logistic information system (LIS), management of any logistic company (LC) is difficult to optimally and operatively perform complex management even in normal market, non-crisis conditions. Consequently, the actual purpose of designing a new and / or reengineering existing LIS is to improve the efficiency of functioning of the logistic processes of the enterprise, optimization of all its business processes, taking into account global and sectoral, ordinary and crisis influences.

In the article, considering the industry specificity of the transport industry, the system problems of existing classical logistic systems are investigated and revealed, taking into account the following global trends for 3PL companies: mergers and acquisitions, Big Data problems, the importance of introducing Data Mining technologies for anti-crisis Fraud Detection, the relevance of corporate Knowledge Management technologies.

Taking into account the above-mentioned results and considering the results of the previous author's research the comprehensive cross-cutting method of anti-crisis reengineering of forest in crisis macroeconomic phenomena has been developed.

Considering the substantiated (in previous studies of the authors) the relevance and positive effect of the joint, hybrid-script use of Big Data, Data Mining and Knowledge Management technologies, the algorithm of an adaptive knowledge based LIS with the planning and ranking of relevant information flows and management impacts has been developed.
\end{abstract}

Conclusions. The obtained results are relevant and applicable not only for local logistic companies, but also for international applications in the context of projected global macroeconomic and current national crisis phenomena. Data Mining.

Keywords: crisis management; logistic company; reengineering; information system; knowledge management; 
Удк: 004.41/[004.67+004.89]:005.7/656/338.1

Краснюк М. Т., кандидат економічних наук, доцент, доцент кафедри інформаційних систем в економіці, Київський національний економічний університет імені Вадима Гетьмана, м. Київ, Україна

Гращенко I. C., кандидат економічних наук, доцент, доцент кафедри менеджменту зовнішньоекономічної діяльності підприємств, Національний авіаційний університет, м. Київ, Україна

Краснюк С. О., старший викладач, Київський національний університет технологій та дизайну, м. Київ, Україна

Кустаровский О.Д., аспірант, Київський національний економічний університет імені Вадима Гетьмана, м. Київ, Україна

\section{Реінжиніринг логістичної компанії та їі інформаційної системи з урахуванням макроекономічної кризи}

Анотація. Сучасна економіка характеризується не лише процесами нарощування глобалізації та конкуренції на ринках, мобільністю та інтернаціоналізацією ресурсів, швидким розвитком інноваційних інформаційних технологій, але й одночасним швидким поширенням кризових явищ в середині та між економіками. Всі ці фактори висувають нові вимоги до ефективного корпоративного управління.

Таким чином, для забезпечення стабільності не тільки в умовах поточної глобальної ринкової конкуренції та макроекономічних кризових явищ всі ефективні компанії (в т. ч. логістичні) повинні мати здатність швидко та ефективно пристосовуватися до змін, тобто повинні бути системно адаптивними.

Враховуючи вищенаведену актуальність та результати попередніх досліджень авторів, розроблена методика інноваційної реорганізації логістичної компанії шляхом її реінжинірингу в рамках реалізації політики антикризового менеджменту.

Треба зазначити, що неодмінною складовою будь-якої системи менеджменту є відповідна адекватна та ефективна інформаційна система. Саме тому, без актуальної, ефективної та адаптивної логістичної інформаційної системи (ЛІС), менеджменту будь-якої логістичної компанії складно оптимально та оперативно здійснювати комплексне управління навіть в звичайних ринкових, не кризових умовах. Отже, актуальною метою проектування нової та/або реінжинірингу наявної ЛІС є покращення ефективності функціонування логістичних процесів підприємства, оптимізація всіх його бізнес-процесів з урахуванням глобальних та галузевих, ординарних і кризових впливів.

У статті з урахуванням галузевої специфіки транспортної галузі та глобальних тенденцій для $3 P L$ компаній досліджено та виявлено системні проблеми наявних класичних логістичних систем: злиття та поглинання; проблеми Big Data; впровадження технологій Data Mining для антикризового Fraud Detection; актуальність корпоративного Knowledge Management.

Враховуючи попередні авторські дослідження, розроблена комплексна наскрізна методика антикризового реінжинірингу ЛІС в умовах кризових макроекономічних явищ.

Враховуючи обгрунтовану актуальність та позитивний ефект від спільного, гібридно-сценарного використання технологій Big Data, Data Mining ma Knowledge Management розроблена схема адаптивної орієнтованої на знання ЛІС з плануванням та ранжуванням відповідних інформаційних потоків та керуючих впливів.

Отримані результати є актуальними та прикладними не тільки для локальних логістичних компаній, але і для міжнародного застосування в умовах прогнозованих глобальних макроекономічних та поточних національних кризових явищ.

Ключові слова: антикризовий менеджмент; логістична компанія; реінжиніринг; інформаційна система; управління знаннями; Data Mining.

Statement of the problem. The modern global economy is characterized not only by processes such as the globalization of markets, the internationalization of enterprises, the rapid development of innovative information technologies, but also the rapid spread of crisis phenomena between cooperative economies, increasing global demands for total business efficiency, and they all put forward new demands for corporate management.

In today's global trade environment, a complicated phenomenon is evident in the sector of logistics services:
- on the one hand, logistics operations across end-toend supply networks have become more complicated and vulnerable to both macroeconomic and microeconomic level factors;

- at the same time, the logistics' service providers have been significantly affected by the crisis and these effects have influenced all the main functional areas of the logistics management (procurement, warehousing, inventory management, transportation and distribution) [2].

Therefore, to ensure stability, not so much in the conditions of global market competition, as especially in the context of microeconomic and macroeconomic crisis 
phenomena, enterprises (including logistic) should be able to adapt quickly and efficiently to changes, that means that, they should be adaptive [3].

Without an up-to-date, efficient and adequate logistic information system (LIS), management of any logistic company is difficult to optimally and operatively implement integrated management, even using such classical techniques of logistic management as: integration of the chain of value creation, estimation of route efficiency, use of intelligent information technologies, communication optimization, demand forecasting, in-depth cost analysis, scenario-based approach to modeling [4].

The main purpose of designing new and / or reengineering existing LIS is to improve the efficiency of functioning of the logistic processes of the enterprise, optimization of all its business processes.

Currently, the need for designing new and reengineering existing classical LIS in the developed countries of the European Union and North America is mainly stimulated by the results of mergers and acquisitions, the Big Data problem and the subsequent globalization in the markets, and in the second place - the need for more rapid reaction of producers to the market conditions.

And in our country, taking into account national and industry specifics, it can be argued that the relevance of the task of studying the features of designing and reengineering the LIS is updated not only by the importance of being able to detect and respond promptly to ad-hock microeconomic events during the course of economic activity at the domestic logistic market, but also the importance of adapting in response to systemic and dynamic macroeconomic threats in conditions of a systemic crisis.

Moreover, the state of the economy in Ukraine can clearly be characterized as both systemically and subjectively crisis $[5 ; 6]$.

That is, an actual, effective and adaptive LIC in a forwarding company provides not only an additional competitive advantage, but also is an important anti-crisis tool.

Analysis of recent research and publications. In general, the number of literary sources that explores the applied questions of the functioning of enterprise logistic information systems is small. Among domestic and international experts, the main contributions to the formation of the theory of classical information logistics were made by Ye. V. Krykavskyi and N. V. Chornopyska [7], M. P. Denysenko, P. R. Levkovets and L. I. Mykhailova [8], A. Ye. Batiuk, Z. P. Dvulit and K. M. Obelovska [9], O. Matviienko and M. N. Tsyvin [10].

However, both domestic and foreign research, the actual and applied tasks concerning the development of a comprehensive methodology of reengineering LC (within the framework of crisis logistic management) and, consequently, re-designing or re-engineering of LIS, considering not only national and industrial specifics, are completely unsolved, but also given the global relevance of using Data Mining and Knowledge Management technologies in the logistic business.

Setting objectives. Taking into account the above, research and analysis of the features of designing and reengineering of LIS; development of an appropriate comprehensive cross-cutting methodology of anti-crisis reengineering of the LC and its LIS; the development of a conceptual high-level scheme of adaptive knowledgebased LIS (with relevant information flows) for a domestic LC under the conditions of a systemic crisis are important issues of the article, which are important not only for domestic logistic companies, but also for international application (especially considering the World Bank forecasts for the future global macroeconomic crisis).

Methodology. The object of this study is the business processes of logistic company management and relevant information flows. The subject of the study is anti-crisis reengineering of both the logistic company and its LIS. The basic terminology and theoretical basis for this study are presented in the next section. Used methods: critical analysis of existing literature, analysis of the empirical professional experience of the authors in the field of logistics, system and functional analysis of logistic systems, structural and logical analysis and synthesis in the development of the method of reengineering LC and LIS.

The main part. For the design or reengineering of the LIS, one must take into account the theory of structural construction of logistic systems. Consequently, each logistic system is based on the commonality of elements (links), between which there are certain connections and relationships. The link of the logistic system is an economical or functionally autonomous object, which is indivisible within the chosen level of analysis (functional task).

Links of the logistic system can be of three main types: those that generate streams, those that transform them and consumers; the relevant information flows respond them. More often, there are mixed types of a logistic system, in which the three characteristics listed are combined with each other.

In the links of the logistic system, material, money, information flows can be united, distributed and change their characteristics. The links of the logistic system may be individual enterprises, their subdivisions [11].

When designing a LIS, it is necessary always to pay great attention to the general principles of building the LIS [12]:

1) The principle of reliability and accuracy assumes no errors in the formation of the database of accumulated information.

2) The principle of continuity means the systematic collection, accumulation and processing of information.

3) The principle of efficiency and timeliness arises due to the requirement of rapid market research and the search for the necessary information through the 
continuous dynamic of the external environment of the enterprise activity.

4) The principle of rationality and completeness of information gathering involves the search for only the necessary information concerning the activity of the enterprise and its collection in full to form a comprehensive analysis and decision-making.

5) The principle of frugality is determined by the precious information and causes optimization of the cost of receiving and processing information.

6) The principle of simplicity provides that the information must be provided so that the recipient could understand it.

7) The principle of the clarity of the information flow information should not be very complex (lack of information overload) and should comply with the principle of simplicity.

8) The principle of relevance occurs because the information is necessary to allow its recipient to solve the problem or make a decision.

9) The principle of adequacy aroses due to the need to match the content of information according to material and other stream processes.

When designing the structure of logistic systems, one must take into account the specific characteristics of the individual component of the logistic system [13]:

1) various forms of ownership and organizational-legal forms, corresponding features in the nature and purpose of their work;

2) different power and concentration of the used technological equipment and resources used;

3) geolocation of technical means and labor resources in a large area;

4) high mobility of vehicles;

5) the dependence of the results of the activity on a large number of external factors and related units.

The great variety of types of links in the logistic system and the variety of their characteristics and connections makes it difficult to design and further manage the logistic system.

The main requirements that must be taken into account when designing a modern LIS for a domestic logistic enterprise are as follows:

- synchronization and coordination between financial, information, logistic and material logistic flows;

- consistency, concordance and complexity of actions of different time periods, different levels of management;

- the reality of the tasks, the correct and complete use of information, the optimal adoption of logistic solutions.

In accordance with the principles of a systematic approach, any system must first be investigated in a relationship with the environment, and then within its structure. This principle must be respected when designing logistic information systems.

In non-crisis conditions, there are several main approaches to defining the main objective in the construction and design of LIS:
- minimizing the costs of the logistic chain;

- ensuring the greatest adaptability, elasticity and reliability of logistic operations;

- a mixed integrated indicator of the purpose of designing LIS.

Also, important factors to consider when designing logistics systems are:

1. Information on the logistic market (its composition, scale, static; number of buyers and their features; placement of customers; demand flexibility; legislation; policy of state logistics regulation);

2. Information on production (in the case of production logistics) (need for material resources, fixed assets, components and raw materials; production methods; equipment availability and capacity utilization; production rate; duration and specificity of the production cycle);

3. Information on material flows (characteristic of the specificity and state of material flows; information on the characteristics and conditions of transportation of goods);

4. Information on information flows (characteristics of the specificity and status of information flows; data about the system of information provision; the method of processing and preservation of information; the way of obtaining and disseminating information; the potential of storage and accumulation of information; data on the reliability and relevance of logistic information flows).

5. Information about financial flows and their characteristics.

6. Geoinformation on the location and parameters of warehouses, terminals, clients, etc.

The indicator of the logistic cycle is also an important characteristic of logistic systems, and it should be taken into account when designing them.

The logistic cycle consists of:

1) time for ordering in a certain order;

2) the time for transfer and delivery of the order to the supplier;

3) the time of execution of the order by the supplier, which includes: the waiting period of the order, the period of execution of the order. The waiting period for an order consists of: the working time required for manufacturing products and the time of interoperable downtime during the production, the time of receipt of finished products. The execution period of the order may consist of the time of packing and packaging time, if the order is executed from the available stocks from the manufacturer or reseller;

4) time of delivery of finished goods to the customer.

The ability not only to localize LIS but also to the parallel operation of information systems and technologies makes it possible to systematically approach the management of logistic flows, providing processing and exchange of large volumes of information between different participants in the logistics process.

The process of development / reengineering of logistic systems should consider all of the abovementioned 
logistic principles and requirements, and involves coordinated interaction and coherence of all the above preconditions, taking into account the influence of external factors.

LIS is characterized by poly structure, which is expressed in the interpenetration of different subsystems. In addition, we emphasize once again that, in a dynamic crisis situation, the LIS does not only have to use adaptive algorithms, but its structure either periodically or in Adhock mode must be verified and, if is necessary, must be changed.

Let's outline the main areas of works in the design, creation and implementation of LIS:

- the technical means for executing the program task are determined;

- the requirements for qualitative characteristics are formed and the necessary amount of financial and labor resources is determined;

- the basic methods of formation of program tasks are determined;

- the organizational forms of implementation of program tasks are selected;

- network models of stages and works are being drawn up;

- systems of criteria for evaluation and action motivation are developed;

- control, accounting and evaluation of work progress are organized.

In addition, there is the next version for a strategic planning approach to LIS design processes, which includes the following steps:

- definition of enterprise divisions that will be included in the integrated information system (also taking into account the prospect);

$-a$ rough draft of the functional areas of the information system and the relationships between them;

-identification of objects important for the enterprise's operation (customers, suppliers of materials, parts, etc.) and their display in the information system (this is the most difficult task of strategic planning, is closely related to the previous step);

- definition of possibilities of using functional areas of the system in different divisions of the enterprise and estimation of the expected effect;
- the establishment of rules for the architecture and technical implementation of subsystems and interconnecting units created by their own forces;

- the establishment of general rules and formats independent of the functions of the data transmission between the functional areas of the information system;

- installation of parameters for computing equipment (hardware equipment, operating system, data management system, technical methods of transmission);

- development project implementation (priorities, terms, etc.).

However, taking into account the task of the research, none of the above methods for designing or reengineering an adaptive LIS for a domestic logistic company is not adequate, especially considering the abovementioned systemic crisis phenomena.

Therefore, taking into account the above, below, in Fig. 1, the author outlines the cross-cutting method of anti-crisis reengineering of LC.

Detailing at step 4 the developed complex crosscutting methodology of anti-crisis reengineering of LC, it is necessary to consider not only the author's taxonomy of applied anti-crisis tactical techniques within the national, sectoral and corporate levels, but it is necessary to take into account the taxonomy of applied anti-crisis measures considering phases of the crisis (pre-crisis, core motivation of strategy and after-crisis strategy) [14].

In addition, further analyzing the proposed method in Fig. 1, it is important to emphasize that anti-crisis plans for LC and anti-crisis program effectiveness are depended on many variables like the observed time frame, the type of $\mathrm{CM}$ entity, its organizational level or the specific crisis situation.

Following a literature analysis [15], it is compiled a set of performance indicators in the areas information dissemination, involvement of top management in crisis management tasks, cooperation with stakeholders, financial measures, stakeholders' confidence in the sustainability of an organization, documentation, and time for making specified improvements. 


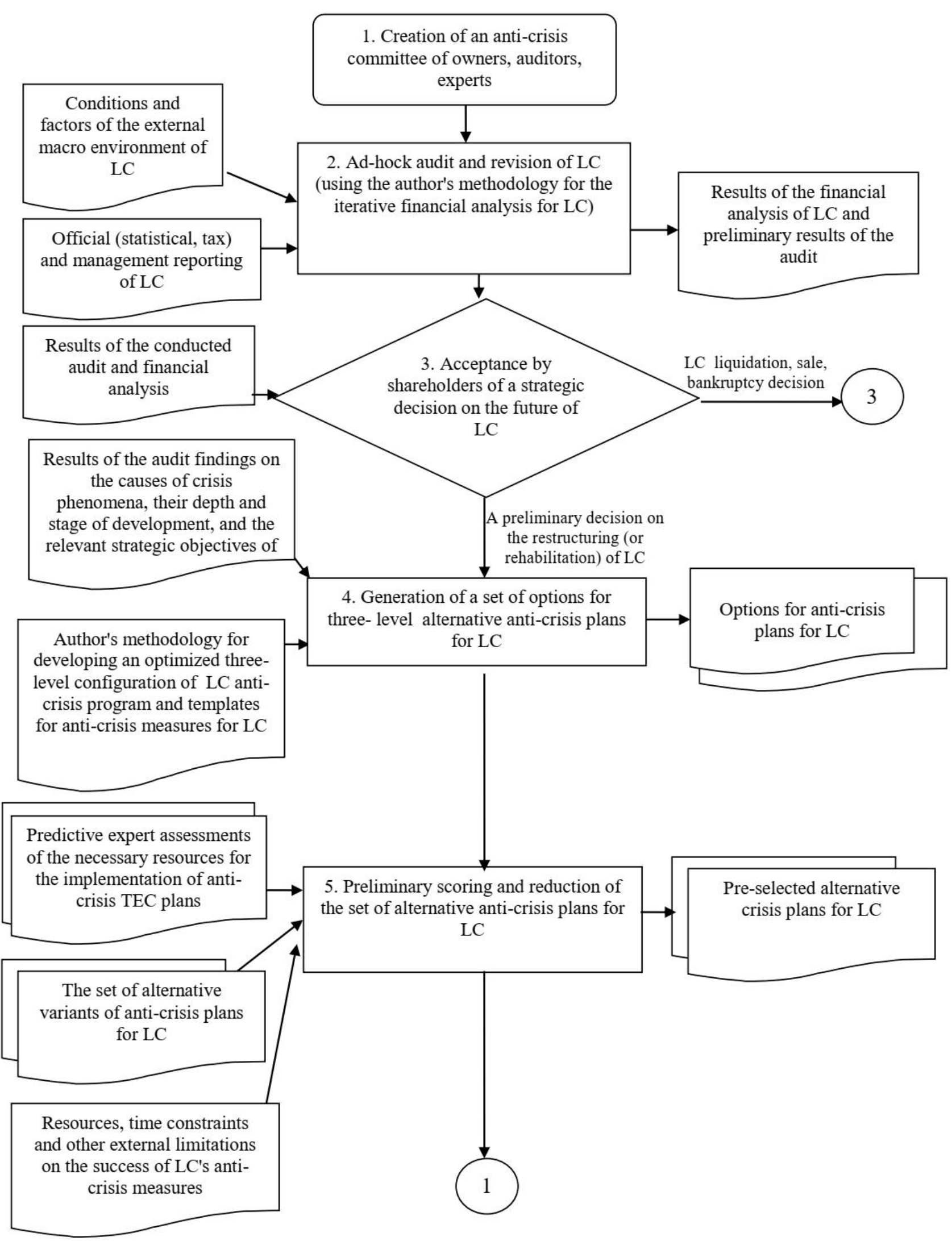

Fig. 1. The scheme of the developed complex cross-cutting methodology of anti-crisis reengineering of LC and LIS, sheet 1 


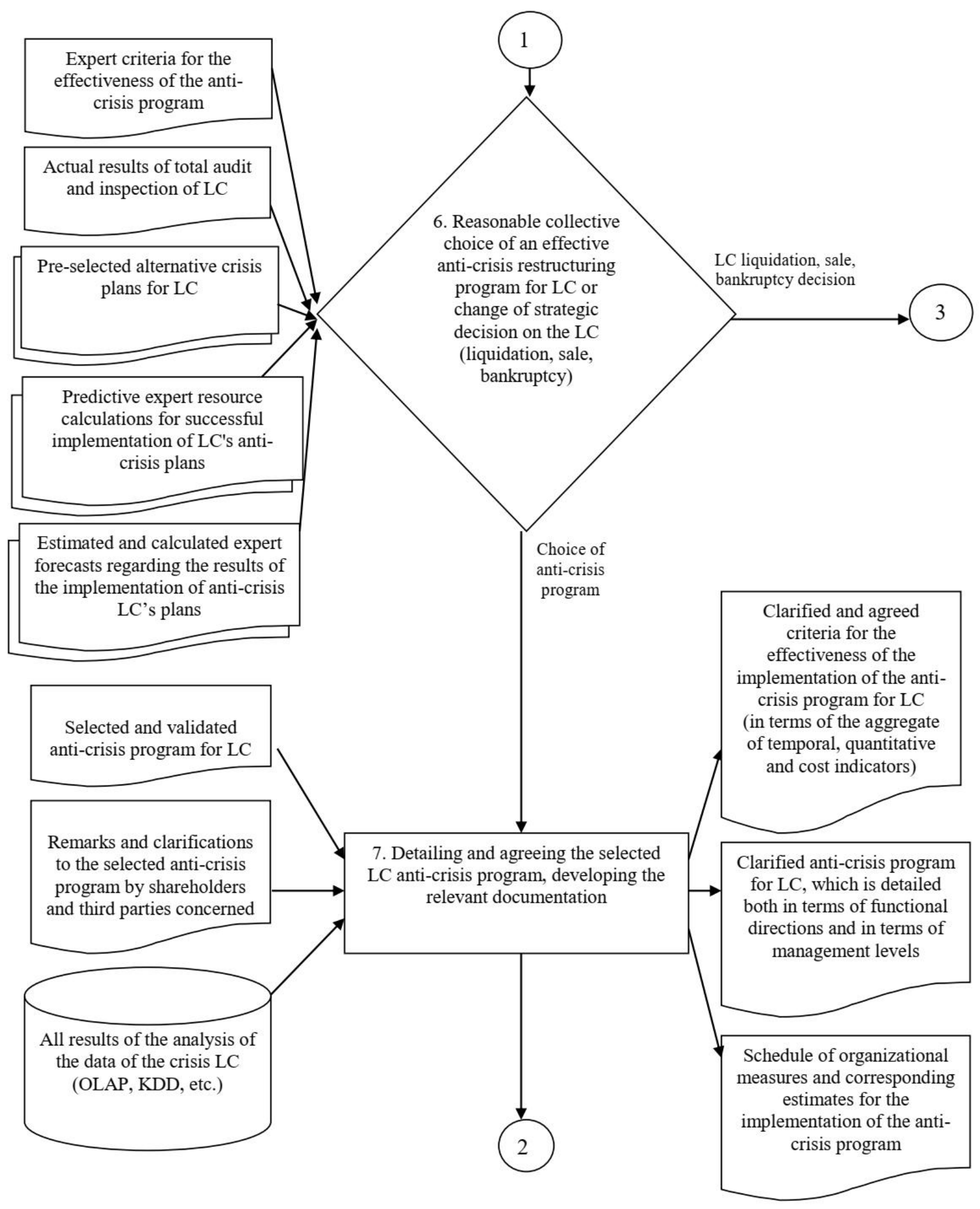

Fig. 1. The scheme of the developed complex cross-cutting methodology of anti-crisis reengineering of LC and LIS, sheet 2 

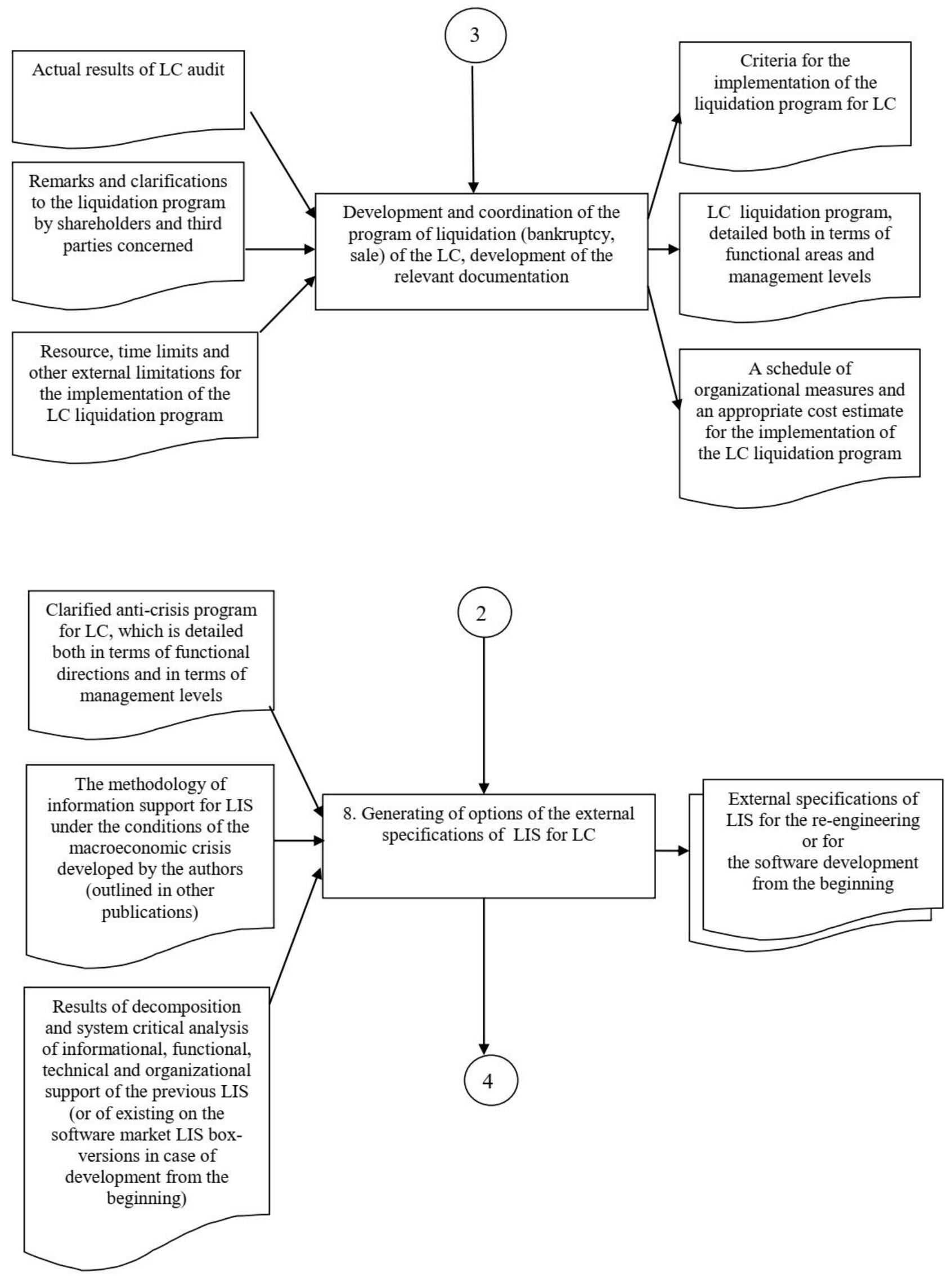

Fig. 1. The scheme of the developed complex cross-cutting methodology of anti-crisis reengineering of LC and LIS, sheet 3 


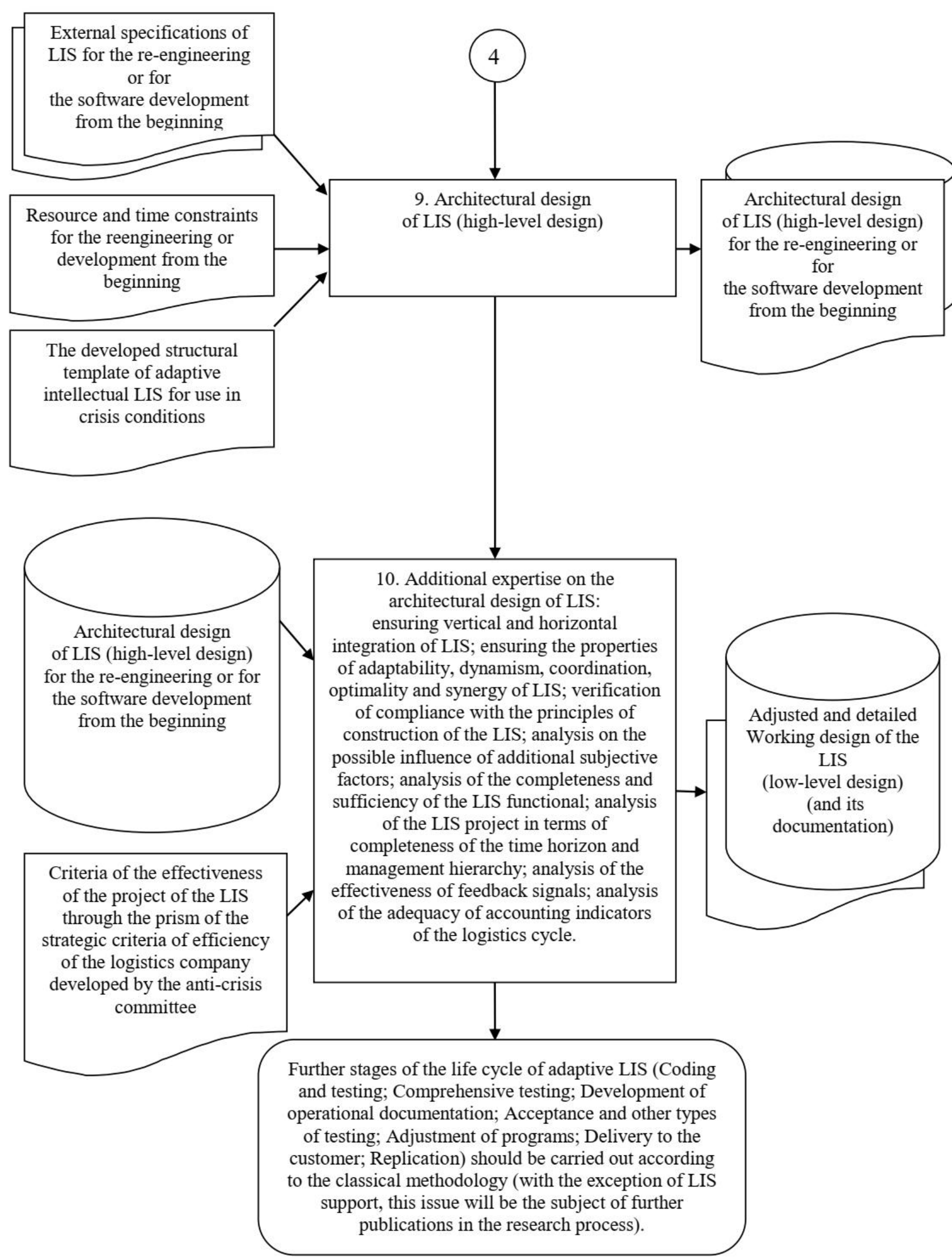

Fig. 1. The scheme of the developed complex cross-cutting methodology of anti-crisis reengineering of LC and LIS, sheet 4 
Results. Therefore, with further details of the proposed developed complex cross-cutting methodology of anti-crisis reengineering of LC there is a need of the design and development of a measurement framework that evaluate anti-crisis plans for LC and anti-crisis programs in linking with strategies, technical systems, crisis management objectives etc. (steps \# 4,5 and \#6 from fig. 1).

An important stage in further applied research into the effectiveness of the implementation of the developed complex cross-cutting methodology of anti-crisis reengineering of LC and LIS is the need to detail the reengineering / configuration the supply chain risk management frameworks and models, which should be applied to step \# 7 from fig. 1 . and, in the course of such detail and development, it is suggested that besides [16], should be taken into account the research results [17].

It should be noted that the intellectual LIS must be integrated into all areas of the enterprise activity (marketing, management, production, finance, etc.). The basic concept of constructing an intellectual LIS is based on the principle of clear interaction and coherence of functional elements. With this approach, within the framework of the logistic system integrate all corporate functions, such a system solves in the global plan the following key issues: production, development of the general concept of commodity movement, the choice of rational material flows, determination of inventory volume, the amount of storage capacity required for their storage, the need for their expansion or new construction, the amount of capital investments is needed, both for increasing production and for expanding warehouse space.

The developed concept and structure of intellectual LIS should (along with the traditional functions of logistic management) have a wide functional for controlling the main logistic operations (loading and unloading, acceptance of cargo, marking and bar coding, registration of receipt and disposal, repackaging, assembly, etc.), especially in automated mode of fraud detection.

In other words, huge amounts of OLTP and OLAP, accumulated in organizations contain many potentially useful hidden patterns that may and need to be used for current and strategic optimization. However, simple methods of analysis, such as intelligence visualization, in this case cannot help. They allow us to answer only the question: "what was," but it is needed to get an answer to the question: "what to do", "what will happen". This requires mechanisms for constructing predicative models that can find non-trivial patterns in large volumes of data, that is, the use of Data Mining technologies, and at the next stage of development and technology KDD.

The current development of logistic enterprises should be aimed at improving managerial analysis and strategic modeling and planning on the basis of such in-depth intellectual analysis. Innovative LIS models are developed in conjunction with the processes of reengineering of business processes and information flows. Logistic enterprises, in the context of the systemic or sectoral crises, should proceed to a complete reorganization and optimization of logistic procedures, reducing the number of functional cycles and volumes of related activity, in particular due to the efficient intelligent logistic information systems.

Consequently, based on the research carried out by the authors, a scheme of adaptive LIS LC in the conditions of the existing crisis macroeconomic phenomena is projected (Fig. 2). 


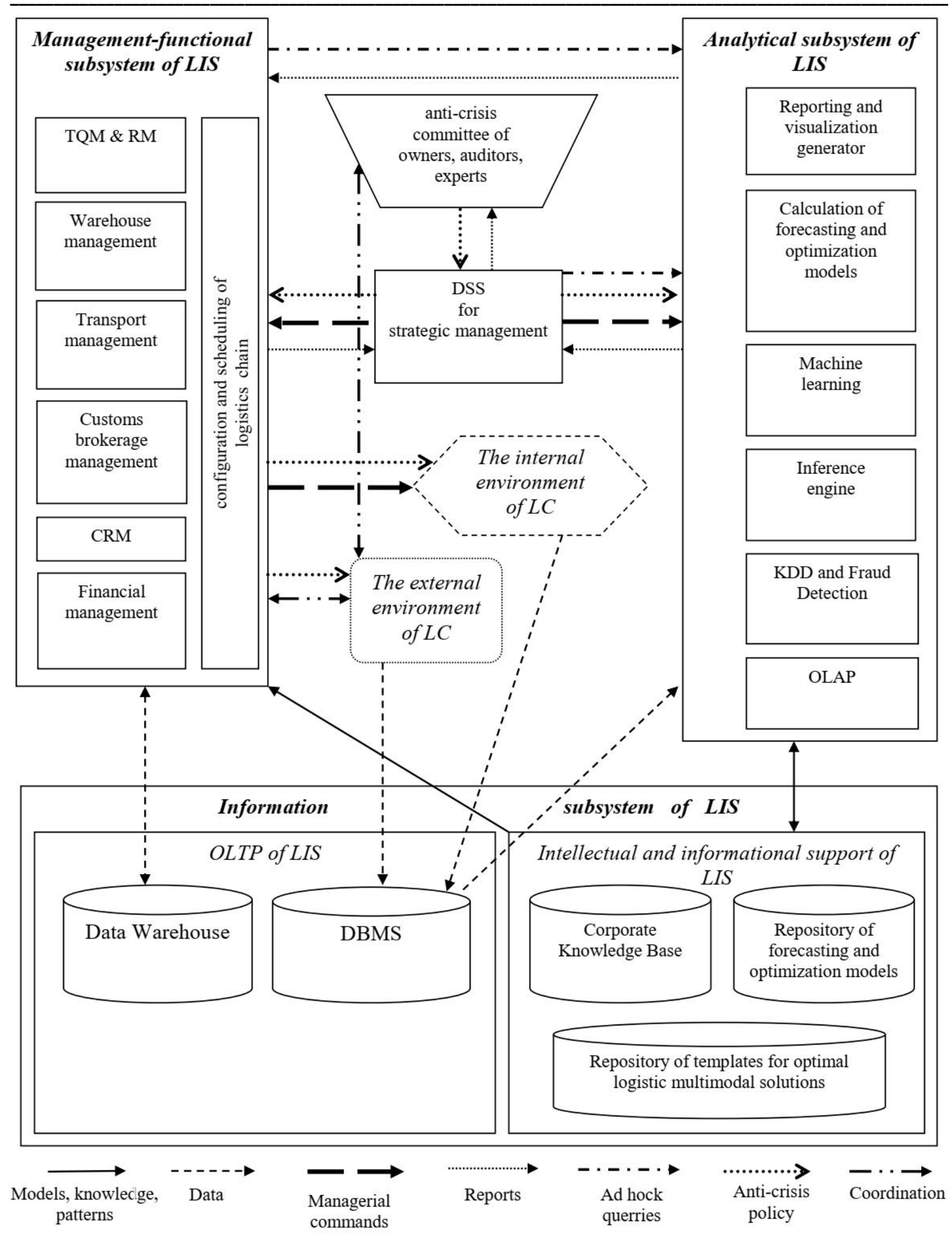

Fig. 2. The high-level scheme of adaptive knowledge-based LIS (with appropriate information flows) for a domestic LC under the conditions of a systemic crisis 


\section{Conclusions and suggestions.}

This article is written on the basis of the obtained scientific and practical results in the course of complex collective research on the topic: "Methods and models of restructuring of transport and expeditionary business in the conditions of the macroeconomic crisis".

It should be noted that the scientific and practical results outlined in this article, complex and systematically take into account the following published author's results concerning:

- Problems and perspectives of development of logistic information systems in the conditions of a globalized economy and macroeconomic crisis phenomena;

- The development of the concept and set of practical measures of anti-crisis logistics management in the current Ukraine conditions;

- Adaptation of methods and improvement of models of financial analysis of transport industry enterprises in current crisis macroeconomic conditions;

- Improvement of the economic-mathematical modeling of the results of implementation of individual elements of the adaptive anti-crisis policy of the transport industry companies;
- Methodology and optimal configuration of the model of forming anti-crisis program of logistics company in the conditions of the system crisis;

- Methodology of effective application of Big data and data mining technologies as an important anti-crisis component of the complex policy of logistic business optimization.

Thus, the article proves the relevance and gives the results of research on:

- analysis of features of designing and reengineering of LIS;

- development of an appropriate comprehensive cross-cutting methodology of anti-crisis reengineering of the LC and its LIS;

- development of a conceptual high-level scheme of adaptive knowledge oriented LIS (with appropriate information flows) for domestic LC under conditions of systemic crisis.

The results obtained are relevant and applicable not only for specific logistics companies (which are in crisis), but also for international corporate use in the context of possible future global macroeconomic crisis phenomena.

\section{References:}

1. Richard Partington (2018). IMF warns storm clouds are gathering for next financial crisis. The Gurdian: International edition. Retrieved from https://www.theguardian.com/business/2018/dec/11/imf-financial-crisis-david-lipton [in Ukrainian].

2. Folinas, D., Tsolakis, N. \& Aidonis, D. (2018). Logistics Services Sector and Economic Recession in Greece: Challenges and Opportunities. Logistics, 2, 16. DOI: 10.3390/logistics2030016.

3. Katerna, O. K. (2018). Concept formulation of intelligent management in transport. Modern Economics, 9(2018), 30-42. DOI: https://doi.org/10.31521/modecon.V9(2018)-04.

4. Krasnyuk, M. \& Kustarovskiy, O. (2017). The development of the concept and set of practical measures of anti-crisis logistics management in the current Ukraine conditions. Management theory \& practice: Warsaw Management University, 19 (1), 31-38.

5. Sytnik, I. V. \& Stopochkin, A. I. (2015). The model for the deployment of crisis phenomena in the economy of Ukraine in the context of modern geopolitical transformations. Visnyk KrNU imeni Mykhaila Ostrohradskoho, 6/2015 (95), 9-16 [in Ukrainian].

6. Trunina, I. M. (2015). Analysis of the Entrepreneurship Environment in Ukraine. Visnyk KrNU imeni Mykhaila Ostrohradskoho, 4/2015 (93), 116-122 [in Ukrainian].

7. Krykavskyi, Ye. V. \& Chornopyska, N. V. (2009). Lohistychni systemy [Logistics systems]. Lviv: Vydavnytstvo Natsionalnyi universytet "Lvivska politekhnika" [in Ukrainian].

8. Denysenko, M. P., Levkovets, P. R. \& Mykhailova, L. I. Orhanizatsiia ta proektuvannia lohistychnykh system [Organization and design of logistic systems]. Kyiv: Tsentr uchbovoi literatury [in Ukrainian].

9. Batiuk, A. Ye., Dvulit, Z. P. \& Obelovska, K. M. (2004). Informatsiini systemy $v$ menedzhmenti [Information systems in management]. Lviv: Vyd-vo Nats. un-tu "Lvivska politekhnika" [in Ukrainian].

10. Matviienko, O. V. \& Tsyvin, M. N. (2005). Osnovy menedzhmentu informatsiinykh system [Fundamentals of Information Systems Management]. Kyiv: Tsentr navchalnoi literatury [in Ukrainian].

11. Bezukladov, S. V. (2004). Improvement of information technologies of logistic systems on the basis of the principle of optimal structural proportions. APE, 9, 13-20 [in Ukrainian].

12. Pytuljak, N. S. (2013). Improving the functioning of logistics information systems. Visnyk Chernighivsjkogho derzhavnogho tekhnologhichnogho universytetu. Serija: Ekonomichni nauky, 2, 152-157 [in Ukrainian].

13. Krasniuk, M. T. \& Kustarovskyi, O. D. (2017). Problems and prospects of development of Ukrainian logistics and information systems in the conditions of a globalized economy and macroeconomic crisis phenomena. Investytsii: praktyka ta dosvid, 10, 34-39 [in Ukrainian].

14. Stavros, T. P. \& Ntalla, A. (2015). Crisis management practices and approaches: Insights from major supply chain crises. 3rd Global Conference on Business, Economics, Management \& Tourism, Rome, Italy Retrieved from https://www.researchgate.net/publication/286151963.

15. Widera, A., Fonio, Ch. Lechtenberg, S. \& Hellingrath, B. (2018). Measuring Innovations in Crisis Management. 15th International Conference on Information Systems for Crisis Response and Management, Rochester, NY Retrieved from https://www.researchgate.net/publication/325283498_Measuring_Innovations_in_Crisis_Management . 
Електронне наукове фахове видання з економічних наук “Modern Economics», №13 (2019), 141-153 https://modecon.mnau.edu.ua | ISSN 2521-6392

16. Herashchenko, I. S., Krasniuk, M. T. \& Kustarovskyi, O. D. (2018). Improvement of the economic and mathematical modeling of the results of implementation of individual elements of the adaptive anti-crisis policy of the transport industry companies of Ukraine. Naukovyi visnyk Uzhhorodskoho universytetu Seriia «Ekonomika», 1 (51), 205-211 [in Ukrainian].

17. Stavros, T. P., Ntalla, A. \& Koronis, E. (2014). Supply chain risk management frameworks and models: A review. Conference: European Academy of Management 2014 Retrieved from: https://www.researchgate.net/publication/262915406.

Ця робота ліцензована Creative Commons Attribution 4.0 International License 